\title{
Reshaping Colonial Subjectivities Through the Language of the Land
}

\section{Lewis Williams}

Whakauae Research for Māori Health and Development, Whanganui, New Zealand.

\section{Abstract}

This paper focuses on the regenerative capacity of Indigenous languages to heal humanity's widespread disassociation from our earth. Decolonization is positioned as the collective work of reindigenization as this pertains both to Indigenous peoples and those who are no longer indigenous to place. In doing so, the paper elucidates the potential contribution of the Westernized field of ecopsychology, with its focus on the interrelationships between well-being, human culture, and environment. In particular, it focuses on elements of the new science, relational psychology, and poststructuralism to elucidate the ways in which Indigenous languages might enliven, shape, and consolidate human subjectivities and agency for sustainable futures. Drawing on Te Ao Māori (the Māori LifeWorld) and other Indigenous realities, it shifts the debate from Indigenous languages as a human right specific to Indigenous peoples, to Indigenous languages as an ecological imperative for humanity. Key Words: Decolonization-Indigenous languages-ReindigenizatonSustainability-Ecopsychology-Intercultural.

(c) Lewis Williams 2019; Published by Mary Ann Liebert, Inc. This Open Access article is distributed under the terms of the Creative Commons License (http:// creativecommons.org/licenses/by/4.0), which permits unrestricted use, distribution, and reproduction in any medium, provided the original work is properly cited.

\section{Introduction}

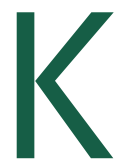

oia tēnei: ko te toroa noho au, e tangi ana ki tōna kāinga; e mihi ana.

This is a fact: I live like an albatross, crying out to its nesting place and greeting you (in sorrow). ${ }^{1}$

In Te Ao Māori (the Māori LifeWorld), the deeper meanings behind human experience are often encoded within whakatau $\bar{a} k \bar{i}$ (proverbs) which, prior to colonization, were exclusively passed between generations within the oral traditions of Māori, the Indigenous peoples of Aotearoa. These critical messages or sayings provided and continue to provide a significant means of sense-making between past and present. Today they remain an important method for transmitting critical intergenerational information about all aspects of life, including traditional knowledge, tribal memory, historic events, behavior, and personal achievement (Whaanga \& Wehi, 2016). While primarily composed in relation to the specificities of time, particular events, and places-in this case the confiscation of Māori land and the resultant spiritual and economic alienation for Māori-the metaphorical nature of whakataua $\bar{k} \bar{\imath}$ means that they invariably carry deeper and larger meanings about experiences of life, as well as guidelines for ethical human behavior more generally. Perhaps the most distinguishing feature of te reo Māori (the Maori language), according to Māori worldview, is that Māori regard the act of speaking their mother tongue as a "worlded" (Mika, 2016) gathering of entities intimately related to place, space, and time (Mika, 2016; Mika \&t Stewart, 2017). This is probably the primary defining attribute that sets it apart from Western languages like modern English, which are grounded in Cartesian or separatist views of reality.

In contemporary modernist society, use of te reo Māori (for example, its application within public policies) has in many respects become institutionalized, decontextualized, and disjointed from the

\footnotetext{
${ }^{1}$ Māori proverb used to refer to the confiscation of lands and the displacement of Māori from their homes.
} 


\section{RESHAPING COLONIAL SUBJECTIVITIES}

sovereignty of its ecological origins (Williams, 2018). In this paper, as I write about the potential of Māori and other Indigenous languages to deepen our relationship with the earth (reindigenization), I also insert an important caveat. The use of te reo Máori and other Indigenous languages, particularly by those with varying degrees of dislocation from their indigenous origins, needs to be attuned to the specifics of whakapapa (genealogy) of land and waterscapes, people and language. Without deep appreciation for place and ecological specificity, their indiscriminate application risks exacerbating colonial dominance, a point I return to later in this article.

The central thesis of this paper has four key tenets. First, probably our greatest capability in supporting reindigenization is the innate human capacity for deep empathic connection to the earth as a living being (Ausubel, 2008; 0'Hara, 2006; Williams, 2012b). Second, disrupted by historical and contemporary forms of colonialism, this capacity is threatened by the dissonance between our often fleeting experiences of interconnectedness, and everyday priorities and actions, as anchored in and influenced by our everyday contexts and political ecologies (Williams, Bunda, Claxton, \& MacKinnon, 2017). Third, a key means of addressing the dissonance between ontology (the nature of reality) and epistemology (how we come to know, or our everyday actions) is through the resurgence of Indigenous languages. Language acts as a medium for mediating and connecting the reciprocal and reflexive relationship between our embodied experiences of place and the ways in which we construct and articulate our relationship to place. Fourth, given the extent to which the worldviews underpinning Indigenous languages are at odds with the modernist views of reality that underscore many culturally dominant languages such as English, care must be taken that the use of Indigenous languages by non-Indigenous speakers does not subvert reindigenization.

In this paper, I take the position that ecopsychology, particularly genres based on participatory worldviews, can make an important contribution to understanding the role of Indigenous languages as a significant strategy for effecting necessary shifts in human consciousness and behavior. There is also, however, a critical distinction to be made between participatory and Indigenous worldviews. While both share the view of a deeply interconnected and mutually constituted reality, Indigenous worldviews, ways of being and languages, arise from specific places and therefore convey unique sets of human-ecological understandings and relationships (Williams et al., 2017). As will become apparent later in this paper, this distinction is important for understanding both ecopsychology's potential and limitations in elucidating the relationship between Indigenous languages and stronger human-earth connectedness.

I am a Ngāi Te Rangi (a tribe that is indigenous to Aotearoa) woman who is also of non-Indigenous ancestry (Celtic and Ger- manic). Shortly following the confiscation and partial return of our lands, my great-grandfather, Edward Sellars, came to Tāmaki Makaurau (Auckland), Aotearoa, where I grew up. After a series of dreams related to my iwi (tribal) identity, in 2003 I returned to my ancestral lands-the Tauranga Moana (literally the seas of Tauranga) which refer to an interconnected network of ocean, waterways, wetlands, farmland, and forests-and reconnected with my iwi and some of our Kuia (female Elders) and Koroua (male Elders). While most of my formal education and professional training was strongly influenced by Western, Cartesian dualism, much of the heart of my reality is Te Ao Māori. Today I live in the Tauranga Moana, learning the language of my people and working with Whakauae Research Services, a Māori health and development organization. Given my dual epistemological and cultural lineage, and that my professional life has given me ample opportunity to observe the impacts of public discourses on our relationship to the earth, I am deeply interested in processes of "becoming of place" and the relational spaces, practices, and theoretical traditions that might enable this (Fig. 1).

\section{Indigenous Languages: From Human Right to Ecological Imperative}

Languages with their complex implications for identity, cultural diversity, spirituality, communication and social integration, education and development, are of crucial importance for people and planet. People not only embed in languages their

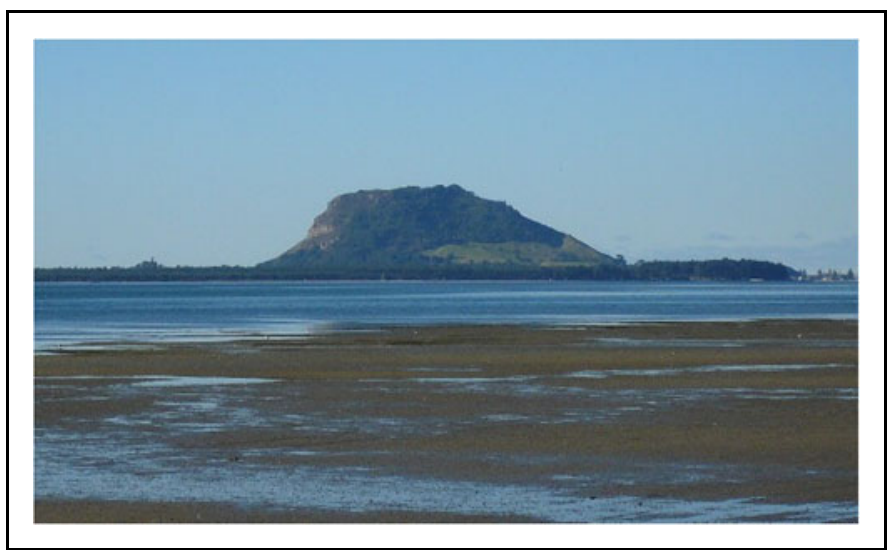

Fig. 1. Looking out onto part of the Tauranga moana with our ancestral mountain Mauao at the harbor entrance in the background. The significance of this is reflected in our tribal pepeha (traditional introduction) which begins Ko Mauao te maunga, Ko Tauranga te moana. Mauao is the Mountain, Tauranga is the sea or space. This signifies nga tangata (the people) and te taiao (the environment) as one. 


\section{WILLIAMS}

history, traditions, memory, traditional knowledge, unique modes of thinking, meaning and expression, but more importantly they also construct their future through them. (UNESCO, 2018, p. 2)

Through giving life to local cultural specificities, customs and values which have endured through time, Indigenous languages are repositories of diversity and key resources for both understanding the environment and utilizing it to the best advantage of local populations, as well as humanity as a whole (UNESCO, 2018). Yet Indigenous languages remain endangered; their links to human sustainability are rarely well-articulated in everyday discourse or public policy. This is the situation in Aotearoa, where despite the government's recognition of te reo Māori as a taonga (a socially or culturally valuable resource) and subsequent strategy to effect the widespread use of te reo throughout the country (Waitangi Tribunal, 2011), the status of te reo Māori remains precarious. ${ }^{2}$ Relatedly, support for te reo Māori focuses almost exclusively on Māori identity, and well-being. For example, a recent report on the significance of language to national development and progress by the Royal Society of New Zealand (2013)-an institution at the apex of knowledge legitimization in the country-positions language as "the primary means of interpreting reality and therefore ... basic to cultural evolution and change" (p. 2). Te reo Māori, however, is solely discussed within the same report "as a marker of [Māori] cultural persistence" that is [solely] of critical importance to "Māori identity and wellbeing” (pp. 4-5). At international levels, similar trends are apparent. The United Nations Declaration on the Rights of Indigenous Peoples (United Nations, 2008) positions the interrelated issues of Indigenous languages, cultural practices, and sustainability (Articles 5, 13, 25, 29) as "human rights specific to Indigenous Peoples" rather than an integral part of a much more complex global social-ecological system, underscored by the dynamic interaction between human cultures and ecosystems. Meanwhile, the 2030 Agenda on Sustainable Development (United Nations, 2015) largely ignores the critical role of partnerships with Indigenous peoples. Overall, Indigenous peoples continue to be framed as "vulnerable populations"; their inalienable

\footnotetext{
${ }^{2}$ Rates of conversational Māori among Māori declined from 25.2 to 21.3 percent in 2001 and 2013, respectively (Ministry of Social Development, 2016). These declines in te reo Māori were in part the subject of a treaty of Waitangi claim (commonly known as WAI 262) made by Māori against the Crown, focused on enabling Māori to take back control of Māori identity and culture within New Zealand policy and law-making. Set up by the Treaty of Waitangi Act 1975, the Waitangi Tribunal is a permanent commission of inquiry that makes recommendations on claims brought by Māori relating to actions by the Crown which breach the promises made in the Treaty of Waitangi.
}

right to sustainable cultural, social, and economic development is perceived as a human right solely concerning Indigenous peoples, rather than an imperative for human continuance.

The poor understanding of the potential of Indigenous languages to heal the fractures between human and earth consciousness lies in part on the emphasis on their transactional value (Derby, 2016), rather than the worldviews that underpin them and their deeper relevance to human being and experience. In Te Ao Māori, language is closely linked to whakapapa (the genealogy between all entities). The expression of this whakapapa or kinship with other beings throughout te reo Māori is reflected in the following words of a young Ngāi Te Rangi woman leader:

I think looking at the sea and land, it's much deeper than what the eye sees ... it definitely impacts the way I think about things ... When I speak Māori, it's more metaphorically speaking and I am often referring to something in the way the sea moves ... I often talk about the waves, because our people are such sea people. (Williams, 2012a)

Making these kinds of whakapapa connections occurs through recitation of ancestral lineage, stories, narratives, verse, whakatauki (proverbs), moteatea (laments), pepeha (formulaic expressions of tribal identity), waiata (songs), and kōrero (conversation). Together, these expressions of mātauranga Māori (Māori knowledge) validate wairua (spiritual) attachment to the lands and waters and the life that is of them, as well as mahinga kai (their practical use for survival through cultivation or food gathering) and sense of well-being or mauri (life force) (Awatere, Harmsworth, \&t Robb, 2017). Furthermore, for Māori, as entities possess their own mauri and are part of the unseen world, a word or concept has equal ontological value as those entities that constitute the seen material world. As the binding life force energy that interpenetrates and connects all of life (animate and, in the Western sense, inanimate), mauri is the animating energy that impels the cosmic process forward (Marsden, 2003). In this interconnected worldview, any one entity is immediately and actively constituted by all things-thinking, and therefore language, arises from the communion of entities in place with each other (Williams, 2012b).

In contrast to colonizing worldviews which position language as the representation of discrete objects or entities that are somehow separate from the whakapapa of the world, Māori philosophy views language as bringing the world "into presence." It is a sort of gathering of entities rather than merely an instrument for singling out any one thing (Mika, 2016). Within Te Ao Māori, the interconnected totality of things "culminate[s] in one utterance"; that which is being manifested through language is "fundamentally unknowable and never the less influential and constructive" (2016, p. 171). Furthermore, human beings 


\section{RESHAPING COLONIAL SUBJECTIVITIES}

are not alone in their capacity for language; other entities in the world have the power to speak (Moon, 2003) in accordance with their own essential autonomy yet in accordance with each other (Mika, 2016, p. 169). Te reo Māori as embedded in place and people holds important knowledge not only of the environment but in relational ethics-the protocol for how to be in relationship with human and other than human life-forms-otherwise known as "Te reo me $n g \bar{a}$ tikanga" (the language and the cultural protocols) (Derby, 2016).

\section{Reshaping Colonial Subjectivities Through the Language of the Land}

Ko te reo te mauri o te mana Māori.

Language is the lifeforce of Māori.

At its core, ecopsychology can be broadly thought of as the "synergistic relationship between personal [human] and planetary wellbeing"-the needs of each being relevant to the other (Norton, 2009, p. 140). This definition encompasses a wide range of ontological, epistemological, and theoretical approaches, ranging from more individualistic and anthropocentric tenets of Western psychology that seek to understand how the earth community might service human well-being (Jiang, 2013) to deeply participatory worldviews that decenter human consciousness and needs (Abram, 1996; Woodbury, 2013). Particularly notable within the ecopsychological literature and relevant to the aims of this paper is the observation that its critical dimension is ill-equipped to engage alongside decolonial praxis (Jones \& Segal, 2018).

Methodologically, the recovering of Indigenous cultural ecologies and knowledge systems-the "reproduction of culture in place" (Sommerville, 2010)-draws on previous scholarship in critical Indigenous studies and social geography (Kraidy, 2002; Fredericks, 2013). Also relevant to this discussion are two key theoretical strands which align with the recollectivist and critical dimensions of ecopsychology, respectively. The first (recollectivist dimension) is the remapping of ontology and epistemology in an embodied sense upon the human psyche through ceremony, stories, arts-based approaches, and simply being one with country. The second (critical dimension) is the remapping of sociohistorical narratives that involves the disruption of dominant settler narratives of the ecology of culture and place through resurfacing and repositioning Indigenous narratives of country, culture, and kin (Williams et al., 2017).

Recollective dimension and the reproduction of culture in place ${ }^{3}$

The recollective dimension of ecopsychology, particularly theoretical approaches aligned with relational psychology and participatory

${ }^{3}$ Parts of this section draw on Williams (2012b, 2013). worldviews (Abram, 1996; Chalquist, 2007; Fessenden, 2007; Woodbury, 2013), has much in common with Indigenous onto-epistemologies. In recent years, the West's hiatus from the science of interconnectedness (for example, as practiced by the earlier alchemists, see Chalquist, 2007, p. 94) has been broken by what sustainability educator Elizabeth Lange (2012) refers to as the "new science," an emergent paradigm within Western scientific approaches "predicated on relativity theory, quantum physics, complexity and chaos theory, enactivism, gaia theory and deep ecology" (p. 199). The new science accounts for what Indigenous science has long known: Consciousness is collective, matter and energy are fundamentally expressions of the same thing, and our "Life-World" (Williams, 2012b, p. 93) is inherently an alchemical one as energy (including consciousness) and matter are mutually transformative. As Lange (2012) states:

At the subatomical level, matter and energy are interchangeable as either particles or waves affecting each other synergistically and emergent with the act of human observation ... thus matter and mind coemerge as an intimately interlinked system within a larger bio-sphere ... Potentially we have access to this transpersonal consciousness based on our holistic or expansive self [LifeWorld] .... (p. 199)

The new science aligns well with Indigenous "LifeWorld” (Williams, 2012b, p. 93) perspectives which view consciousness as embedded in the nature of all things. Learning is holistic and relational, involving "human beings, animals, plants, the natural environment, and the metaphysical world of visions and dreams" (Fixico, 2003, p. 2). These theoretical frameworks resonate well with embodied forms of the reproduction of culture in place as, from an Indigenous worldview, it is the body's knowing or perceiving that informs other levels of consciousness (Cajete 2000; Broadhead \& Howard, 2011)-a point on which Western scholarship on relational consciousness (Abram, 1996; Chalquist, 2007; Merleau-Ponty, 1964) is instructive. In particular, the work of Maurice Merleau-Ponty, French phenomenological philosopher, as articulated in his seminal book The Primacy of Perception (1964), and David Abram's (1996) thesis of an "Ecology of Language" lay important theoretical groundwork not only with demonstrating the primacy of the embodied nature of human language and its decentering as an exclusive human property (Abram, 1996, p. 78) but also in articulating the reflexive relationship between embodied and discursive forms of human communication.

These theoretical perspectives resonate with Te Ao Māori. For example, decentering language as a uniquely human attribute is evident in the art of moko (tattooing of the skin), in which manu (bird) patterns were traditionally used around the eyes for men and around 


\section{WILLIAMS}

the lips for woman. That is because, as conveyed by one tohunga tā moko (tattooing expert), in Te Ao Māori: "Birds are messengers, ${ }^{4}$ they fly in the realms of the atua (gods)" (Williams, 2012a).

Expanding further on the aforementioned Western perspectives regarding the reflexive relationship between embodied and discursive forms of communication, for Merleau-Ponty, the body's structures of perceptual consciousness are our first route of access to being and truth: "such structures underlie and accompany all the other structures of higher-level individual consciousness" (1964, p. xvi). Similarly, within David Abram's ecology of language, prior to discursive language, preverbal communication is already in exchange. This exchange has its own coherence and articulation, suggesting that perception is the very soil and support of the more conscious exchange we call language (Abram, 1996, p. 74). It is this gestural, somatic dimension of language that is always present and underpins its abstract structure (Merleau-Ponty, 1964). Within Te Ao Māori, tā moko (Māori tattooing) is an example of the gestural expression language, representing somatic experience and the embodiment of the Māori LifeWorld. In this way "all moko talk about the whenua (land), wai (water) Tangaroa (sea), Tawhiri Mātea (the wind) and Rangi (the sky)" (Williams, 2012a). The reflexive and intimate relationship between these embodied forms of language and its more abstract nature is evident in the historic naming of places throughout Aotearoa by Māori after parts of the body (Taonui, 2019) (Fig. 2).

The theories described in this section which represent participatory rather than Indigenous worldviews are significant in terms of enabling understanding (for people of Western epistemological lineage) of how taking time to "be" with the land and our other relatives can facilitate deepening into place. While a critical entry point into understanding the interconnections between place-specific epistemologies and Indigenous languages, these theories are insufficient on their own to facilitate indigenous connections to place for humanity at large.

\section{Critical dimension and the reproduction of culture in place}

The following two examples demonstrate the ways in which Indigenous languages can potentially reconstitute colonial subjectivities. In te reo Māori, one word for waterfall is wairere. Wai refers to water, while rere refers to a range of movements which include to "fly, flow, flee, leap ... go into action (any gliding movement), rush, run, race, [and] descend" (Moorefield, 2011). In

${ }^{4}$ For example, in Te Ao Māori, a single pīwakawaka coming into a house is considered to be a messenger that a loved one is soon to pass to the spirit world.

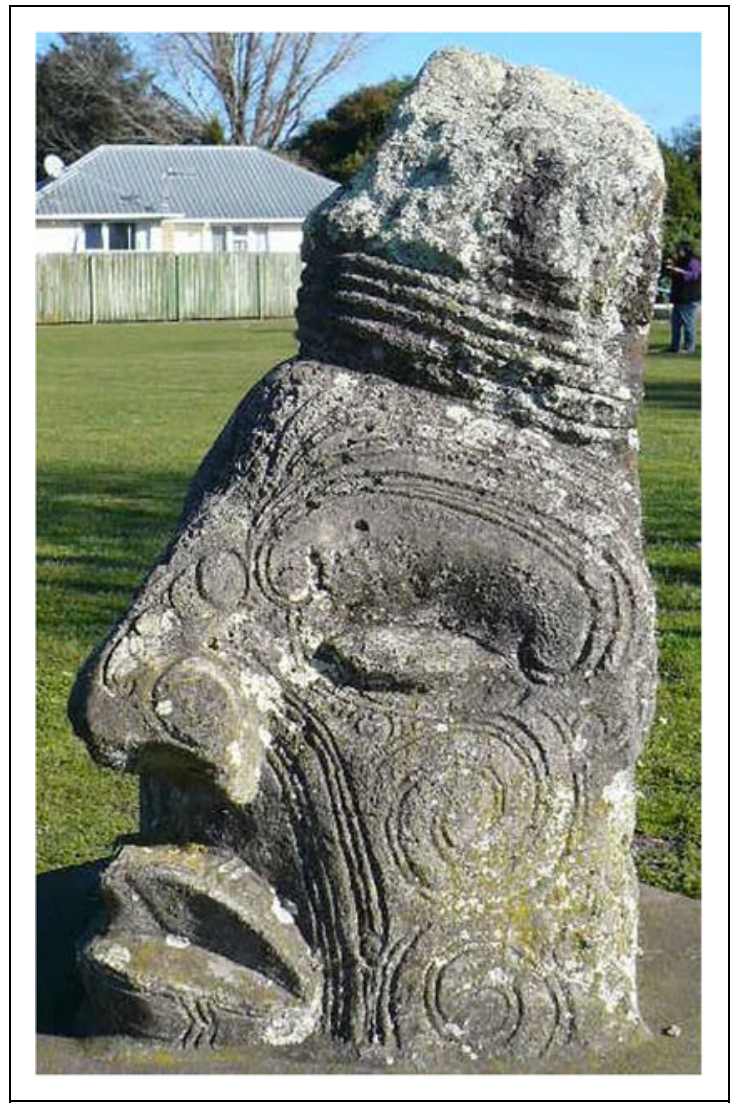

Fig. 2. The stone figure of Taneatua, at the town of Taneatua, Bay of Plenty. Taneatua was the tohunga or priest on board the Mataatua, the author's ancestral waka (Canoe). The moko (carvings on his face) represent his whakapapa-genealogical relationship to the rest of creation.

alignment with Te Ao Màori, in which the universe and life within it is interconnected by a unitive fabric of energy (mauri) including the spoken word, the word rere brings the water to life as an animate being which has a range of movements. The wai (water) does not just fall but flows, leaps, flies, and so on. Similarly, language educator April Charlo of the Bitterroot Salish People of Western Montana discusses how the interrelationship between language and experiences shapes our concepts of the world around us. Prior to colonization, interactions with the natural world were not framed through the concept of ownership but rather "relationship." For example, in the dialect of her people the word Sewtkw means water. However, on its own Sew means to ask whilst $k^{w}$ means liquid. For 


\section{RESHAPING COLONIAL SUBJECTIVITIES}

Charlo (2018) this denotes that her ancestors, knowing in a very immediate sense how critical water was to their survival, did not take water for granted. The word "Sewłk" toward a respectful relationship with water.

Ecopsychology, through its embrace of relational psychology and the more critical aspects of Western poststructuralist (Conley, 2006; Foucault, 1984) and feminist (Weedon, 1997) theory, can contribute toward understanding how Indigenous languages can reshape human subjectivity and action in ways that teach us how to live within the requirements of place. Working in concert with one another, these theoretical framings of human agency are vital to elucidating the ways in which Indigenous languages can harness the embodied, interconnected but (often less conscious) nature of human experience through place-orientated worldviews of language which shape human subjectivity in ways that facilitate deep relational changes in human thinking and behavior. At institutional levels, Foucault's (1984) concept of the "discursive field" which theorizes a field of power relations as permeating any particular discourse is significant for its ability to facilitate critical understandings of contemporary power relations between Indigenous and non-Indigenous languages. ${ }^{5}$

Relatedly, the place and epistemological specificity of Indigenous languages, however, requires discernment in their use by those not indigenous to the ecological origins of a language or dialect. The significance of this issue is underscored by the fact that the nonIndigenous population majority in colonized, Westernized societies such as Aotearoa/New Zealand often have little to counter their predominantly modernist, separatist experiences of reality-an issue which becomes increasingly critical at institutional levels of power. Within Te Ao Māori, for example, while the grounded and localized nature of the formulaic expressions of te reo Māori such as waitata or whakatuāk $\bar{\imath}$ may be obvious, this is much less apparent in the application of te reo Māori within public policy discourse. For example, hauora is commonly substituted as the Maori word for health within New Zealand public health discourse. However, its meaning is more complex and represents a deeper cosmology than the materialist or social constructionist worldviews that commonly underlie Western language. Hau means breath, and ora means life. Hauora refers to the breath or wind of the spirit which is infused into the process of birth to animate life (Marsden, 2003, p. 60). It is also grounded within the unique genealogical relationships Māori have to land. Regardless of the best of intentions, the concept's generic application within the discursive field (Foucault, 1984) of Western, modernist public policy frameworks risks appropri-

\footnotetext{
${ }^{5}$ See for example the work of McPeek (2011).
}

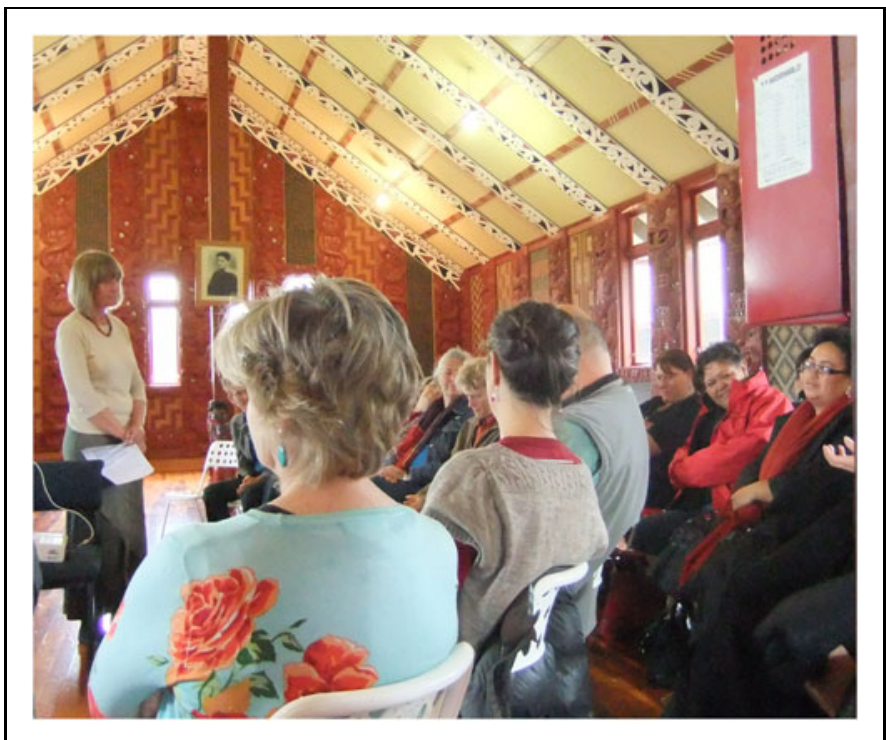

Fig. 3. Lewis Williams (standing to left) facilitating a kinohi ki te kinohi (face to face meeting) with Māori and Pākehā (nonIndigenous New Zealanders) in the Whare Tupuna (ancestral house) at Hoani Waititi marae, Auckland, to discuss the relevance of Māori worldviews and ways of thinking to environmental well-being.

ation. For example, through its decontextualization and translation into the singular word "health," the concept becomes "thinned." While giving the superficial appearance of conveying something "Maori," in reality the concept's tokenistic use actually subverts people's reconnection to holistic ways of well-being that include the land.

A possible way forward through this impasse is through a process of differentiation between the apparent ontology of language, the epistemology of its ecological origins, and the political ecology of its contemporary use. ${ }^{6}$ This capacity for onto-epistemological differentiation-the ability to discriminate between the apparent meaning conveyed within Indigenous languages and their assumed ecological origins, and the political and cultural ecology (dominant worldviews, political interests, and power) within which their use is grounded-will be important to enabling Indigenous languages to shape and consolidate human subjectivities and agency in ways which facilitate Indigenous sovereignty and sustainable planetary futures (Fig. 3).

${ }^{6}$ Elsewhere (Williams, 2018), I have written about frameworks for critical reflection in decolonizing work which may be helpful to this process. These differentiate between various paradigms, political ecologies, and agency imperatives with which they are often aligned. 


\section{WILLIAMS}

\section{Conclusion}

I want my children to come home to something. I want them to hear Māori ... to have that sense of belonging ... not only through the mouth, but through the blood, your mind, body, soul, everything. $^{7}$

Critical to decolonization efforts and the sovereignty of Indigenous peoples over their languages, lands, and lives are Indigenous futures which facilitate the reindigenization of those no longer indigenous to place. Ecopsychology and critical theories at its peripheries can contribute to illuminating the importance of Indigenous languages, and specifically te reo Māori, in potentially contributing to deepened human-ecological relationships. Phenomenology provides an important theoretical bridge in terms of decentering human language as an exclusive human property while the new science illuminates language as an animating life force within an interconnected world. In this sense, language is not in the Western sense representative of an inert world but rather calls into presence a deeply animate world. The Western theories of poststructuralism and the discursive fields are critical to appreciating not only the dominant power relations that can "misplace" or even misappropriate a language but also the agentic potential of te reo Māori in continuing to strengthen the position of Indigenous communities, as well as harnessing the innate capacity of those no longer indigenous to place for an empathic and reciprocal relationship to place through reshaping thinking and behavior. Important to the regenerative capacity of te reo Māori and other Indigenous languages, however, are practices which maintain the integrity of their ecological specificity and origins in relation to dominant Western and institutional forms of power. Given the specificity of Indigenous languages to place, people, and events, their use must strongly center the leadership, realities, and place-specific knowledge of those indigenous to places where they are spoken. Through its centering of participatory and critical theories, ecopsychology potentially plays a vital role in elucidating the significance of Indigenous languages in remaking human-earth connections, while ensuring these processes strengthen Indigenous societies and the integrity of Indigenous languages.

Whatungarongaro te tangata, toitū whenua.

People pass on, but the land remains.

${ }^{7}$ Māori Te Reo Māori leader, Ecology of Wellbeing Project (Williams et al., 2012a).

\section{Author Disclosure Statement}

No competing financial interests exist.

\section{REFERENCES}

Abram, D. (1996). The spell of the sensuous: Perception and language in a more than human world. New York, NY: Pantheon Books.

Ausubel, K. (2008). Preface: Remembering the original instructions. In M. K. Nelson (Ed.), Original instructions: Indigenous teachings for a sustainable future (pp. xxi-xxiii). Roschester, VT: Bear and Company.

Awatere, S., Harmsworth, G., \& Robb, M. (2017). Mātauranga Māori knowledge. In Y. Taura, C. Van Schravendijk-Goodman, \& B. Clarkson. (Eds.), Reo o Te Tepo-The voice of the wetland. Connections, understanding and learnings for the restoration of our wetlands (pp. 151-154). Hamilton, New Zealand: Manaaki Whenua-Landcare Research and Waikato Raupatu River Trust.

Broadhead, L., \&t Howard, S. (2011). Deepening the debate over 'Sustainable Science:' Indigenous perspectives as a guide on the journey. Sustainable Development, 19, 301-311.

Cajete, G. (2000). Native science: Natural laws of interdependence. Santa Fe, NM: Clear Light Publishers.

Chalquist, C. (2007). Terrapsychology: Reengaging the soul of place. New Orleans, LA: Spring Journal Inc.

Charlo, A. (2018). A journey through Indigenous language revitalization: How owning a bug changed the world. Ted ${ }^{x} U$ Montana. 2019 International Year of Indigenous Languages. Retrieved from https://en.iyil2019.org

Conley, V. (2006). Ecopolitics. The environment in poststructural thought. New York, NY: Routledge.

Derby, M. (2016). Te Whanaketanga Ngāi tamarāwaho. The evolution of hapū identity (master's dissertation). Auckland, New Zealand:Auckland University of Technology, Faculty of Te Ara Poutama. Retrieved from https://aut.researchgateway.ac.nz/ bitstream/handle/10292/9721/DerbyM.pdf?sequence =4EtisAllowed=y

Fessenden, L. (2007). Towards a participatory worldview. The Journal of Pedagogy, Pluralism and Practice, 3, 27-44. Retrieved from http://www.lesley.edu/journalpedagogy-pluralism-practice/lily-fessenden/participatory-worldview

Fixico, D. (2003). The American Indian mind in a linear world. New York, NY: Routledge.

Foucault, M. (1984). The Foucault reader (Paul Rabinow, Ed.). New York, NY: Pantheon Books.

Fredericks, B. (2013). We don't leave our identities at the city limits: Aboriginal and Torres Strait Islander people living in urban localities. Australian Aboriginal Studies, 1, 4-16.

Jiang, S. (2013). Therapeutic landscapes and healing gardens: A review of Chinese literature in relation to the studies in Western countries. Frontiers of Architectural Research, 3, 141-153.

Jones, A., \& Segal, D. (2018). Unsettling ecopsychology: Addressing settler colonialism in ecopsychology practice. Ecopsychology, 10, 127-136.

Kraidy, M. (2002). Hybridity in cultural globalization. Communication Theory, 12, $316-339$.

Lange, E. (2012). Transforming transformative learning through sustainability and the new science. In E. W. Taylor \& P. Cranston \& Associates (Eds.), The handbook of transformative learning (pp. 195-211). San Francisco, CA: JosseyBass.

Marsden, M. (2003). The woven universe (Charles Royal, Ed.). Raukawa, New Zealand: Estate of Rev Maori Marsden. 


\section{RESHAPING COLONIAL SUBJECTIVITIES}

McPeek, T. (2011). Killer languages. Language endangerment. Florida Linguistics Association. Retrieved from https://www.youtube.com/watch? $\mathrm{v}=\mathrm{vxs}$ XoLsK6p0

Merleau-Ponty, M. (1964). The primacy of perception. Evanston, IL: Northwestern University Press.

Mika, C. (2016). Worlded object and its presentation. A Māori philosophy of language. AlterNative, 12, 165-176.

Mika, C., \& Stewart, G. (2017). Lost in translation: Western representations of Māori knowledge. Open Review of Educational Research, 4, 134-146.

Ministry of Social Development. (2016). The social report 2016-Te pūrongo oranga tangata. Wellington, NZ: Ministry of Social Development. Retrieved from https://www.msd.govt.nz/

Moon, P. (2003). Tohunga: Hohepa Kereopa. Auckland, New Zealand: David Ling Publishing.

Moorefield, J. (2011). Te aka: Māori-English, English-Māori dictionary. Wellington, New Zealand: Longman/Pearson.

Norton, C. (2009). Ecopsychology and social work: Creating an interdisciplinary framework for re-defining person-in-environment. Ecopsychology, 1, 138-146.

O'Hara, M. (2006). In search of the next enlightenment? The challenge of education for uncertain times. Journal of Transformative Education, 4, 105-117.

Royal Society of New Zealand. (2013, March). Languages in Aotearoa New Zealand. Wellington, New Zealand: The Royal Society of New Zealand. Retrieved from https://royalsociety.org.nz/assets/Uploads/Languages-in-Aotearoa-New-Zealand .pdf

Sommerville, M. (2010). A place pedagogy for 'Global Contemporaneity.' Educational Philosophy and Theory, 42, 326-344.

Taonui, R. (2019). 'Tapa whenua-naming places.' Te Ara - the Encyclopedia of New Zealand. Retrieved from http://www.TeAra.govt.nz/en/tapa-whenua-naming-places

UNESCO. (2018). Action plan for organizing the 2019 International Year of Indigenous Languages. Note by the Secretariat. Permanent Forum on Indigenous Issues. Seventeenth Session, New York, 16-27 April. Follow up to the recommendations of the Permanent Forum. Retrieved from http://www.un.org/en/ga/search/view_ doc.asp?symbol=E/C.19/2018/8

United Nations. (2008). United Nations declaration on the rights of Indigenous peoples. New York, NY: United Nations. Retrieved from https://www.un.org/esa/ socdev/unpfii/documents/DRIPS_en.pdf

United Nations. (2015). Transforming our world: The 2030 agenda for sustainable development. Resolution adopted the seventieth assembly of the United Nations. New York, NY: United Nations. Retrieved from http://www.un.org/ga/ search/view_doc.asp?symbol=A/RES/70/1\&tang $=E$

Waitangi Tribunal. (2011). Ko Aotearoa tēnei. A report into claims concerning New Zealand law and policy affecting Māori culture and identity. Te Taumata Tuatahi. WAI 262 Waitangi Tribunal Report 2011. Wellington, New Zealand:
Legislation Direct. Retrieved from https://forms.justice.govt.nz/search/WT/ reports/reportSummary.html?reportld=wt_DOC_68356054

Weedon, C. (1997). Feminist practice and poststructuralist theory (2nd ed.). Oxford, UK: Blackwell Publishing.

Whaanga, H., \&t Wehi, P. (2016). Māori oral tradition. Ancestral sayings and Indigenous knowledge. Langscape Magazine, 5, 56-59.

Williams, L. (2012a). The ecology of wellbeing. Unpublished Fieldnotes.

Williams, L. (2012b). The human ecologist as alchemist: An inquiry into Ngāi Te Rangi cosmology, human agency and wellbeing in a time of ecological peril. In L. Williams, R. Roberts, \& A. McIntosh (Eds.), Radical human ecology: Intercultural and Indigenous approaches (pp. 91-120). Farnham, UK: Ashgate.

Williams, L. (2013). Deepening ecological relationality through critical ontoepistemological inquiry: Where transformative learning meets sustainable science. Journal of Transformative Education, 11, 95-113.

Williams, L. (2018). Transformative sustainability education and empowerment practice on Indigenous lands: Part one. Journal of Transformative Education, $16,344-364$

Williams, L., Bunda, T., Claxton, N., \& MacKinnon, I. (2017). A global de-colonial praxis of sustainability-Undoing epistemic violences between Indigenous peoples and those no longer indigenous to place. Australian Journal of Indigenous Education, 47(Special Issue on South-South Dialogues: Global Approaches to De-colonial Pedagogies), 41-53.

Woodbury, Z. (2013). Review and response to Radical ecopsychology: Psychology in the service of life (2nd ed.) by Andy Fisher. Ecopsychology, $5,152-157$.

Address correspondence to: Lewis Williams Whakauae Research for Māori Health and Development 60 Ridgway Street Whanganui 4541 New Zealand

E-mail: lewis.williams@usask.ca

Received: December 17, 2018 Accepted: May 4, 2019 